\title{
Identifying Black Spots in Southeast Sulawesi Province, Indonesia: A Combination Method of Equivalent Accident Number and Road Safety Survey Value
}

\author{
Budi Hartanto Susilo, Rhenato Geovan, and Ivan Imanuel
}

\begin{abstract}
Road traffic accidents still become major problems for Indonesia causing more than $\mathbf{2 5 , 0 0 0}$ deaths per year. One of the challenges faced in making road betterments is how to identify and prioritize black spots with minimal accident data. This study offers an innovative approach to combine Equivalent Accident Number (EAN) with other road and traffic parameters which have potentials to cause accidents: average daily traffic, road pavement condition, turning radius, road grade, shoulder width, roadside hazards, and safety facilities, called Road Safety Survey Value (RSSV). The approach was successfully implied on National Roads Southeast Sulawesi Province, showing more accurate ranking of 15 black spots to be treated than the EAN Method.
\end{abstract}

Index Terms-Road safety, black spots, ranking, Equivalent Accident Number (EAN), Road Safety Survey Value (RSSV), Southeast Sulawesi.

\section{INTRODUCTION}

$\mathrm{R}$ oad traffic accidents still become major problems for Indonesia and other nations. It is believed that there is a significant increase in transportation problems regarding efficiency, safety, feasibility, and speed [1]. More than 3,000 deaths and 6,000 serious injuries occur on the road in the world everyday [2]. Data from Statistics Indonesia shows that each year more than 95,000 accidents occur causing more than 25,000 deaths and 130,000 injuries that cause many people become handicapped and unable to work properly [3]. Road casualties and associated physical disabilities tend to impose a large deal of economic cost on governments. It is necessary to perform interventions that have proved to be effective in reducing the accident severity, such as introduction and enforcement of appropriate speed limits, the creation of safer infrastructure, the enforcement of driving behavior, and improvements in vehicle safety [4]. The safer infrastructures should be more implemented in black spots. Identification

B.H. Susilo is with the Department of Civil Engineering, Maranatha Christian University, 40164, Bandung, West Java, Indonesia (e-mail: budiharsus@yahoo.com).

R. Geovan is with the Department of Civil Engineering, Maranatha Christian University, 40164, Bandung, West Java, Indonesia.

I. Imanuel is with the Department of Civil Engineering, Maranatha Christian University, 40164, Bandung, West Java, Indonesia. followed by betterment of existing black spots can significantly contribute to reducing number of the accidents [5].

A large deal of research has been focused on the identification of black spots. For instance, Pignataro and Cantili introduced Equivalent Accident Number (EAN) to determine black spots based on severity levels of the victims [6]. Reshma and Sharif proposed a method in which the accident analysis includes prioritization of some major Black spots using CURVEGIS 10 software package [7]. Chen also used GIS to determine and characterize black spots via spatial analysis [8]. In that paper, a discussion is presented on how to implement geographical coordination technology to record accidents with geographical information attached, and the relation between black spots and traffic features is used analyzing factors affecting the accidents. Agarwal et al. proposed a method for ranking black spots using Analytical Hierarchy Process (AHP) [9]. Their method presents a fourstep ranking approach for black spots wherein no accident information is used. Prieto et al. proposed a modeling road accident black spots data with the discrete generalized Pareto distribution [10]. Machado et al. analyzed and described black spots for vulnerable users of the road including cyclists and pedestrians in Brazil and Italy [11]. The paper determines spots and areas described by the severity of road accidents measured by casualties and injuries in a developing country (Brazil) as well as a developed one (Italy). More modern approaches were shown appeared when Ambros et al. identified of hazardous locations in regional road network by comparison of reactive and proactive approaches [12]. Nguyen et al. addressed an approach towards identification of black spots based on saving road costs [13]. Rouhi and Behzadi managed to prioritize four conventional methods, namely those based on frequency, rate, severity, and rate-severity, and proposed a hybrid method using AHP [14]. La Torre et al. studied a method of accident prediction modeling in Europe that could be applied to different road network using crash modification factors [15]. Susilo modified Pignataro's EAN by rationalizing the average value of EAN from USA, Indonesian National Police, Directorate of Land Transportation, Institute of Road Engineering, and Priyanto to rank black spots in Lampung Province, Indonesia [16]. The 
black spots were ranked by Weighted Accident Number (WAN) to prioritize which one to be treated first. Sugiyanto et al. also used EAN and Upper Control Limit (UCL) method to identify black spots in Purbalingga [17].

Most of the methods proposed for identification of the spots rely on accident information. Traffic accident locations have correlation with the severity of accidents; however some random fatal accidents dominate in the weightings analysis as mentioned in Sugiyanto et al. journal [17]. Analysis with accident information data has another disadvantage that there are still a lot of unreported accidents in Indonesia. WHO Report classified Indonesia as one of the countries without eligible death registration data, with estimated road traffic fatalities $44 \%$ higher than reported [18].

Therefore, there must be a method to support accident information data. Manner and Wünsch-Ziegler stated that accidents caused by the collision with roadside objects, involving pedestrians and motorcycles, or caused by bad sight conditions tend to be more severe compared accidents during daylight and at interchanges or construction sites [19]. So, the road condition itself has some potential to cause accidents. This study offers a new method of Road Safety Survey Value (RSSV) with study case on National Roads in Southeast Sulawesi Province, Indonesia. Southeast Sulawesi Province is a suitable location to conduct the study as the accident data is considered minimum among other provinces in Indonesia. RSSV is intended to support and validate Equivalent Accident Number method, so it is used to provide more accurate overview of the black spots existence as well as to help reduce and prevent the risk of traffic accidents.

\section{Literature REVIEW}

\section{A. Equivalent Accident Number (EAN)}

There are several techniques of crash sites identification and ranking. One famous method to calculate accident number is by using EAN method $[6,16,17]$. There are four types or degrees of accident based on victim severity, so the accident number needs to be weighted by EAN to become WAN. EAN is a numeric economic scale to weigh the degree of accidents. It is calculated by comparing the estimated economic loss caused by various degrees of accident, namely Death Victims (DV), Serious Injuries (SI), Light Injuries (LI), or Property Damage Only (PDO). There are several EAN values suggested by USA Government, Institute of Road Engineering Ministry of Public Works and Housing, Directorate General of Land Transportation, and Indonesian National Police. The rationalized average values of EAN proposed by Susilo [16] are 100 for DV, 20 for SI, 5 for LI, and 1 for PDO, which been approved by Director of Land Transportation Safety to be used in projects or studies, thus the WAN value of a location is calculated as follows:

$W A N=100 D V+20 S I+5 L I+1 P D O$

Where:

WAN $=$ Weight Accident Number

$$
\begin{aligned}
\mathrm{DV}= & \text { Number of Death Victims } \\
\mathrm{SI}= & \text { Number of Serious Injuries } \\
\mathrm{LI}= & \text { Number of Light Injuries } \\
\text { PDO }= & \text { Number of Properties Damaged Only, equals to } \\
& \text { Number of Accidents }
\end{aligned}
$$

\section{B. Road Condition Parameters}

Road condition parameters are used to evaluate road functionality. The road condition parameters are also part of the road planning that is focused on physical, so that it can fulfill its function to provide optimum service. These parameters include: Average Daily Traffic (ADT), road geometry, road pavement, road side hazard, and road facilities.

ADT is the average volume of traffic in a single day. From how to obtain the data are known to two types of average daily traffic, which is the Average Annual Daily Traffic (AADT) and Average Daily Traffic (ADT). ADT or AADT for new road planning is obtained from data analysis obtained from the survey of origin and destination and the volume of road traffic. Road geometry is one of the main factors in planning a road. The safety aspect is highly regarded in designing the geometry of a road. In this study, the aspect of road geometry reviewed is limited to turning radius $(\mathrm{R})$, gradient $(\mathrm{g})$, and roadside width $\left(\mathrm{W}_{\mathrm{s}}\right)$. Pavement condition is a condition that reflects how much the damage value of the road that occurred during the survey (\%). Pavement condition is often expressed and measured by Pavement Condition Index (PCI) method. The greater the PCI value, the better the surface condition of the road as described in Standard PCI Rating Scale, ASTM D 6433-07 [20]. Ideally, the better surface of a road, cause less accidents because it does not interfere with the vehicles or traffic movement. The roadside hazard is defined as the hazard posed by objects and characteristics such as rigid objects with diameters larger than or equal to $(\geq) 100 \mathrm{~mm}$ or trees with diameters $\geq 200 \mathrm{~mm}$, within 2 meters from the edge of the traffic lane for urban and interurban roads with a 20-50 $\mathrm{km} /$ hour, and 4 meters for interurban roads at $50-80 \mathrm{~km} /$ hour. Any existence of this hazard will increase the severity level towards fatality, thus it will be measured by number of hazards $\left(\mathrm{N}_{\mathrm{RSH}}\right)$. Road facilities are guidance for road users (safety fence, guide, curb, sidewalk, signs, marks etc.) placed to meet the comfort and safety requirements. At black spots, a minimum of three facilities must be provided to fulfill the principles of self-explaining, self-enforcing, and forgiving road.

\section{Methodology}

\section{A. Road Safety Survey Value}

This study offers Road Safety Survey Value (RSSV) as a new method to rank black spots according to their road condition parameters. Those seven parameters explained above can be measured through direct field survey. The greater the value reflects the greater chance of accident, which indicates the worse black spot to be ranked. The idea of this method is to define each road condition parameter at its worst condition to be equal to one potential death victim in traffic 
accidents $($ EAN $=100)$. The formula of RSSV is given as follows:

$$
\begin{aligned}
R S S V= & A D T / 200+3000 / R+1000 g+50 / W_{S}+166.7(1-P C I) \\
& +20 N_{R S H}+100\left(1-0.3 N_{F}\right)
\end{aligned}
$$

Where:

$R S S V=$ Road Safety Survey Value

$A D T=$ Average Daily Traffic (vehicle/day)

$R=$ Turning Radius $(\mathrm{m})$

$g \quad=$ Vertical Alignment Gradient (\%)

$W s \quad=$ Width of Road Shoulder (m)

$P C I=$ Pavement Condition Index (\%)

$N_{R S H}=$ Number of Road Side Hazards

$N_{F} \quad=$ Number of Road Facilities

Further, RSSV should be summed with WAN to obtain Final Score $(F S)$ for black spots ranking. As the RSSV represents the potential value of death victims, it is reduced by half. Thus, the FS is calculated as follows:

$F S=W A N+0.5 R S S V$
Where:

$\mathrm{FS}=$ Final Score

WAN $=$ Weighted Accident Number

RSSV $=$ Road Safety Survey Value

\section{B. Data Collection and Surveying}

Secondary data obtained from official website of traffic directorate of Southeast Sulawesi Police [21] shows in 2016 there were 359 accidents along the national roads of Southeast Sulawesi, filtered gradually into 29 black spots with minimum of two accidents at each location. The provincial government agencies of Southeast Sulawesi (Department of Highways, Department of Transportation, and Traffic Directorate of Regional Police) stated that there were 39 black spots. Those two sources of data then were combined and validated to obtain 15 black spots for the field survey. Those black spots are shown in the Figure 1. Field survey was done at all black spots to obtain seven road condition parameters and mark the location site for treatments. AADT data were obtained from National Road Implementing Agency Region VI.

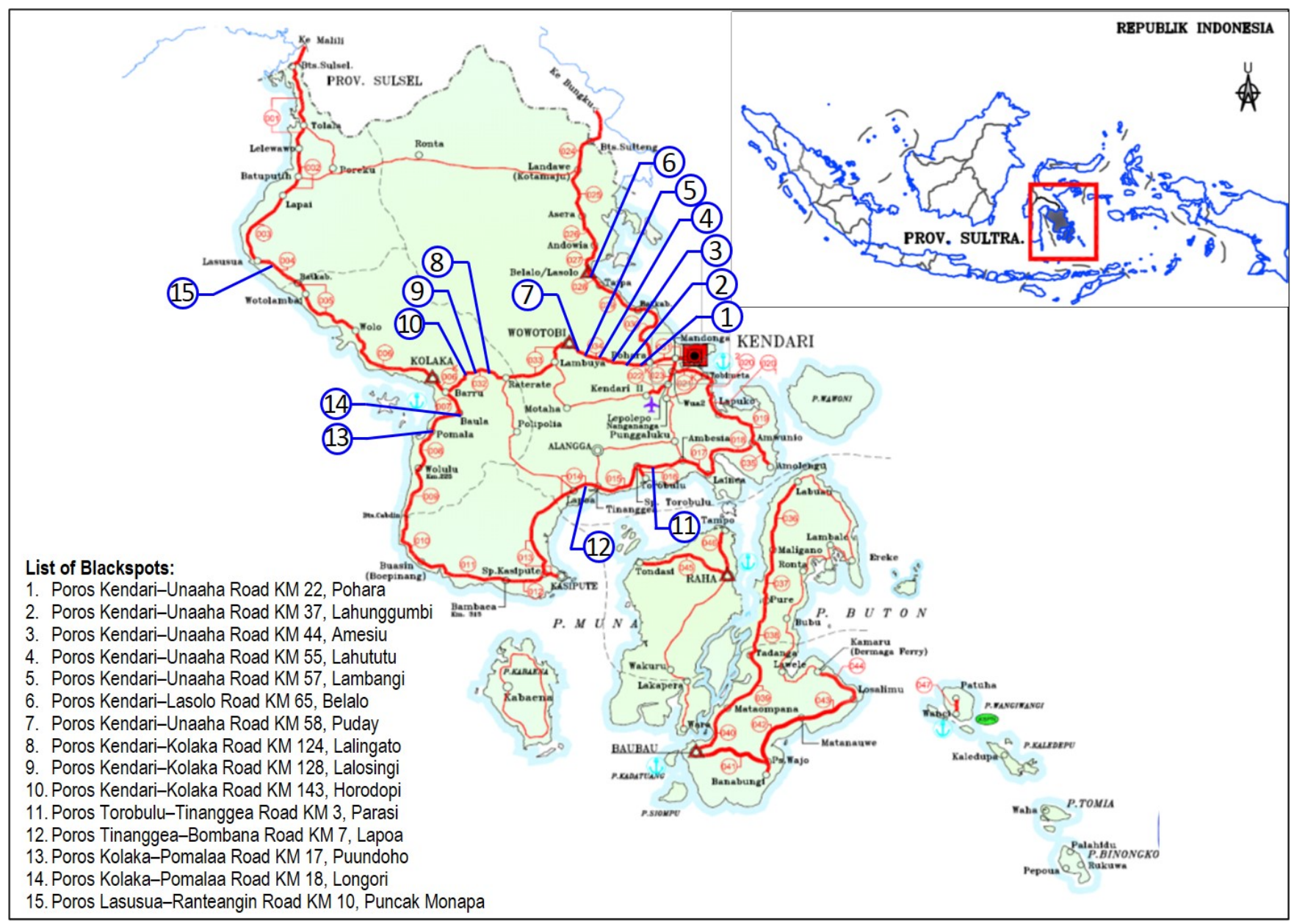

Fig. 1. Location of 15 Black Spots in Southeast Sulawesi Province

\section{ANALYSIS AND RESULTS}

The first step of analysis is to calculate accident data of 15 black spots from Police Traffic Directorate using EAN method. WAN value is obtained by summing up each number of victims multiplied by EAN. An example of calculation in 
Kendari-Unaaha Road KM 22, Pohara, with 1 DV, 3 LIs, and 2 PDOs. The WAN value for this black spot is $1(100)+3(5)+$ $2(1)=117$.

Based on the results shown in Table I, the worst blackspot location is at Kendari-Unaaha Road KM 58, Puday. However, there are three double WAN values occurs in the list $(52,117$, and 142). It proves that with minimal data, the EAN method often produces duplicate values and confounds the black spot rankings. Therefore, another indicator should be added to detail the ranking.

TABLE I

NUMBER OF VICTIMS AND EAN ANALYSIS OF 15 BLACK SPOTS IN SOUTHEAST SULAWESI PROVINCE

\begin{tabular}{lcccccc}
\hline \multirow{2}{*}{ Black Spot Location } & \multicolumn{5}{c}{ Number of Victims } & \\
\cline { 2 - 5 } & DV & SI & LI & PDO & & Rank \\
\hline KM 22, Pohara & 1 & 0 & 3 & 2 & 117 & 8 \\
KM 37, Lahunggumbi & 1 & 0 & 2 & 2 & 112 & 10 \\
KM 44, Amesiu & 0 & 1 & 3 & 2 & 37 & 14 \\
KM 55, Lahututu & 1 & 0 & 3 & 2 & 117 & 8 \\
KM 57, Lambangi & 2 & 0 & 6 & 3 & 233 & 3 \\
KM 65, Belalo & 0 & 2 & 2 & 2 & 52 & 11 \\
KM 58, Puday & 4 & 2 & 4 & 4 & 464 & 1 \\
KM 124, Lalingato & 1 & 1 & 4 & 2 & 142 & 5 \\
KM 128, Lalosingi & 0 & 2 & 0 & 2 & 42 & 13 \\
KM 143, Horodopi & 0 & 1 & 2 & 2 & 32 & 15 \\
KM 3, Parasi & 0 & 2 & 2 & 2 & 52 & 11 \\
KM 7, Lapoa & 1 & 3 & 1 & 3 & 168 & 4 \\
KM 17, Puundoho & 1 & 1 & 4 & 2 & 142 & 5 \\
KM 18, Longori & 1 & 0 & 5 & 2 & 127 & 7 \\
KM 10, Puncak Monapa & 2 & 5 & 10 & 6 & 356 & 2 \\
\hline \hline
\end{tabular}

The RSSV method then is used to complete the analysis. This RSSV method is calculated using the field survey results. The calculations of RSSV on 15 black spots are shown in Table II. The highest RSSV is at Kendari-Kolaka Road KM 124, Lalingato. There is no duplicate value found in the analysis indicating a better certainty for ranking analysis.

TABLE II

ROAD CONDITION PARAMETERS AND RSSV OF 15 BLACK SPOTS IN SOUTHEAST SUlawesi PROVINCE

\begin{tabular}{|c|c|c|c|c|c|c|c|c|}
\hline \multirow{3}{*}{$\begin{array}{l}\text { Black Spot } \\
\text { Location }\end{array}$} & \multicolumn{7}{|c|}{ Road Condition Parameters } & \multirow{3}{*}{ RSSV } \\
\hline & AADT & $\mathrm{R}$ & $\mathrm{g}$ & Ws & PCI & $\mathrm{N}_{\mathrm{RSH}}$ & $\mathrm{N}_{\mathrm{F}}$ & \\
\hline & veh/day & $\mathrm{m}$ & $\%$ & $\mathrm{~m}$ & $\%$ & - & - & \\
\hline $\begin{array}{l}\text { KM 22, } \\
\text { Pohara }\end{array}$ & 8,481 & 30 & 9.8 & 1.5 & 91 & 4 & 2 & 402 \\
\hline $\begin{array}{l}\text { KM } 37 \text {, } \\
\text { Lahunggumbi }\end{array}$ & 8,481 & 500 & 2.1 & 1.5 & 72 & 2 & 1 & 256 \\
\hline $\begin{array}{l}\text { KM 44, } \\
\text { Amesiu }\end{array}$ & 8,481 & 1,200 & 1.9 & 1.5 & 46 & 4 & 1 & 334 \\
\hline $\begin{array}{l}\text { KM 55, } \\
\text { Lahututu }\end{array}$ & 8,481 & 500 & 0.8 & 1.5 & 65 & 3 & 1 & 275 \\
\hline $\begin{array}{l}\text { KM 57, } \\
\text { Lambangi }\end{array}$ & 8,481 & 200 & 1.9 & 1.5 & 77 & 4 & 2 & 261 \\
\hline $\begin{array}{l}\text { KM 65, } \\
\text { Belalo }\end{array}$ & 1,569 & 120 & 3.6 & 1.5 & 75 & 3 & 2 & 237 \\
\hline $\begin{array}{l}\text { KM 58, } \\
\text { Puday }\end{array}$ & 8,481 & 250 & 1.1 & 1 & 52 & 4 & 1 & 342 \\
\hline $\begin{array}{l}\text { KM 124, } \\
\text { Lalingato }\end{array}$ & 8,527 & 20 & 17.1 & 0.5 & 60 & 5 & 0 & 730 \\
\hline $\begin{array}{l}\text { KM 128, } \\
\text { Lalosingi }\end{array}$ & 8,527 & 40 & 7.6 & 1 & 75 & 4 & 1 & 432 \\
\hline $\begin{array}{l}\text { KM 143, } \\
\text { Horodopi }\end{array}$ & 8,527 & 60 & 7.9 & 0.5 & 42 & 5 & 0 & 568 \\
\hline $\begin{array}{l}\text { KM 3, } \\
\text { Parasi }\end{array}$ & 2,322 & 160 & 2.6 & 1 & 48 & 4 & 1 & 340 \\
\hline
\end{tabular}

\begin{tabular}{lcccccccc}
\hline \hline \multirow{2}{*}{$\begin{array}{c}\text { Black Spot } \\
\text { Location }\end{array}$} & \multicolumn{7}{c}{ Road Condition Parameters } \\
\cline { 2 - 7 } & AADT & $\mathrm{R}$ & $\mathrm{g}$ & $\mathrm{Ws}$ & $\mathrm{PCI}$ & $\mathrm{N}_{\mathrm{RSH}}$ & $\mathrm{N}_{\mathrm{F}}$ & RSSV \\
\cline { 2 - 7 } & $\mathrm{veh} / \mathrm{day}$ & $\mathrm{m}$ & $\%$ & $\mathrm{~m}$ & $\%$ & - & - & \\
\hline $\begin{array}{l}\text { KM 7, } \\
\text { Lapoa }\end{array}$ & 8,336 & 8,000 & 1.5 & 2 & 92 & 2 & 1 & 202 \\
$\begin{array}{l}\text { KM 17, } \\
\text { Puundoho }\end{array}$ & 13,182 & 1,500 & 1.0 & 1 & 73 & 3 & 1 & 300 \\
$\begin{array}{l}\text { KM 18, } \\
\text { Longori }\end{array}$ & 13,182 & 4,000 & 1.2 & 1 & 82 & 3 & 1 & 285 \\
$\begin{array}{l}\text { KM 10, } \\
\text { Puncak } \\
\text { Monapa }\end{array}$ & 1,1219 & 130 & 8.8 & 2 & 84 & 3 & 3 & 279 \\
\hline \hline
\end{tabular}

The final step of analysis is to combine WAN with RSSV to determine the final ranking (FS), as shown in Table III. The final rank finds the worst black spot location is at KendariUnaaha Road KM 58, Puday, same as WAN analysis result. The biggest difference is at Kendari-Kolaka Road KM 143, Horodopi which describes more potential of accidents. As the duplicate values are no longer exist, the RSSV has successfully solved the EAN ranking issues regarding lack of accident data.

TABLE III

Final Ranking of 15 Black Spots in Southeast Sulawesi Province

\begin{tabular}{lcccc}
\hline \hline \multicolumn{1}{c}{ Black Spot Location } & WAN & RSSV & FS & Rank \\
\hline KM 22, Pohara & 117 & 402 & 318 & 5 \\
KM 37, Lahunggumbi & 112 & 256 & 240 & 12 \\
KM 44, Amesiu & 37 & 334 & 204 & 14 \\
KM 55, Lahututu & 117 & 275 & 254 & 11 \\
KM 57, Lambangi & 233 & 261 & 364 & 4 \\
KM 65, Belalo & 52 & 237 & 171 & 15 \\
KM 58, Puday & 464 & 342 & 635 & 1 \\
KM 124, Lalingato & 142 & 730 & 507 & 2 \\
KM 128, Lalosingi & 42 & 432 & 258 & 10 \\
KM 143, Horodopi & 32 & 568 & 316 & 6 \\
KM 3, Parasi & 52 & 340 & 222 & 13 \\
KM 7, Lapoa & 168 & 202 & 269 & 9 \\
KM 17, Puundoho & 142 & 300 & 292 & 7 \\
KM 18, Longori & 127 & 285 & 270 & 8 \\
KM 10, Puncak Monapa & 356 & 279 & 495 & 3 \\
\hline \hline
\end{tabular}

\section{CONCLUSION}

The identification and prioritization of black spot in Southeast Sulawesi is presented in this paper. From the analysis and results, it can be concluded as follows:

1. There are 359 accidents on National Roads of Southeast Sulawesi Province in 2016 and 15 black spots have been identified among them.

2. RSSV method has successfully resolved the EAN's black spot ranking issues regarding the lack of accident data.

3. The order of black spot to be treated is Kendari-Unaaha Road KM 58 (Puday), Kendari-Kolaka Road KM 124 (Lalingato), Lasusua-Ranteangin Road KM 10 (Puncak Monapa), Kendari-Unaaha Road KM 57 (Lambangi), Kendari-Unaaha Road KM 24 (Pohara), Kendari-Kolaka Road KM 143 (Horodopi), Kolaka-Pomalaa Road KM 17 (Puundoho), Kolaka-Pomalaa Road KM 18 (Langori), Tinanggea-Bombana Road KM 7 (Lapoa), KendariKolaka Road KM 128 (Lalosingi), Kendari-Unaaha Road KM 55 (Lahututu), Kendari-Unaaha Road KM 37 
(Lahunggumbi), Torobulu-Tinanggea Road KM 3 (Parasi), Kendari-Unaaha Road KM 44 (Amesiu), and Kendari-Lasolo Road KM 65 (Belalo).

\section{REFERENCES}

[1] G. Apparao, P. Mallikarjunareddy, G. Raju, "Identification of Accident Black Spots of National Highway Using GIS," International Journal of Scientific \& Technology Research (IJSTR). 2, 154-157, 2013.

[2] R.R. Sorate, R.P. Kulkarni, S.U. Bobade, M.S. Patil, A.M. Talathi, I.Y. Sayyad, S.V. "Identification of Accident Black Spots on National Highway 4 (New Katraj Tunnel To Chandani Chowk)," IOSR Journal of Mechanical and Civil Engineering (IOSR-JMCE), 12, 61-67, 2015.

[3] BPS-Statistics Indonesia, Land Transportation Statistics 2016, Jakarta, Indonesia, 2016.

[4] Global Road Safety Partnership (GRSP), Speed management: a road safety manual for decision-makers and practitioners, Geneva, Switzerland, 2008.

[5] S. Roudini, M. Keymanesh, A.N. Ahangar, "Identification of Black Spots Without Using Accident Information," Bulletin de la Société Royale des Sciences de Liège, 86, 667-676, 2017.

[6] L.J. Pignataro, E.J. Cantili, Traffic Engineering: Theory \& Practice, Prentice Hall, New Jersey, USA, 1973.

[7] E.K. Reshma, S.U. Sharif, "Prioritization of Accident Black Spot Using GIS," International Journal of Emerging Technology and Advanced Engineering (IJETAE), 2, 117-122, 2012.

[8] H.Y. Chen, "Black Spot Determination of Traffic Accident Locations and Its Spatial Association Characteristic Analysis Based on GIS," Journal of Geographic Information System, 4, 608-617, 2012.

[9] P.K. Agarwal, P.K. Patil R. Mehar, "A Methodology for Ranking Road Safety Hazardous Locations Using Analytical Hierarchy Process, Procedia - Social and Behavioral Sciences," 2nd Conference of Transportation Research Group of India (2nd CTRG), 104, 1030-1037, 2013.

[10] F. Prieto, E. Gomez-Deniz, J.M. Sarabia, "Modelling Road Accident Blackspots Data With The Discrete Generalized Pareto Distribution, Accident Analysis \& Prevention, 71, 38-49, 2014.

[11] C.A.S. Machado, M.A. Giannotti, F.C. Neto, A. Tripodi, L. Persia and J.A. Quintanilha, "Characterization of Black Spot Zones for Vulnerable Road Users in São Paulo (Brazil) and Rome (Italy)," ISPRS International Journal of Geo-Information, 4, 858-882, 2015.

[12] J. Ambros, P. Havránek, V. Valentová, Z. Křivánková, "Identification of hazardous locations in regional road network -comparison of reactive and proactive appro, 6th Transport Research Arena," Transportation Research Procedia, 14, 4209-4217, 2016.

[13] H.H. Nguyen, P. Taneerananon, P. Luathep, "Approach to Identifying Black Spots Based on Potential Saving in Accident Costs," Engineering Journal, 20, 109-122, 2016.

[14] A. Rouhi, G.A. Behzadi, "Prioritizing four methods and Presenting a combination method for determining black spots using Analytical Hierarchy Process (AHP)," Journal of Science and Today's World, 5, 105-109, 2016.

[15] F. La Torre, L. Domenichini, M. Meocci, D. Graham, N. Karathodorou, T. Richter, S. Ruhl, G. Yannis, A. Dragomanovits, A. Laiou, "Development of a transnational accident prediction model, 6th Transport Research Arena, Transportation Research Procedia," 14, 1772 - 1781, 2016.

[16] B.H. Susilo, Guid. Guideline for Survey, "Investigation, and Design of Black Spot Location (SID-BSL) and Its Application in Lampung Province, Indonesia," Civil Engineering Dimension Journal of Civil Engineering Science and Application, 18, 49-56, 2016.

[17] G. Sugiyanto, A. Fadli, M.Y. Santi, "Identification Of Black Spot And Equivalent Accident Number Using Upper Control Limit Method," ARPN Journal of Engineering and Applied Sciences, 12, 528-535, 2017.

[18] World Health Organization (WHO), Global Status Report on Road Safety 2015, Geneva, Switzerland, 2015

[19] H. Manner, L. Wünsch-Ziegler, "Analyzing the severity of accidents on the German Autobahn," Accident Analysis and Prevention, 57, 40-48, 2013.

[20] M.A. Karim, K.A.H. Rubasi, A.A. Saleh, "The Road Pavement Condition Index (PCI) Evaluation and Maintenance: A Case Study of
Yemen, Organization, "Technology and Management in Construction, 8, 1446-1455, 2016.

[21] Ditlantas Polda Sulawesi Tenggara, Laporan Kecelakaan, Retrieved from http://ditlantassultra.com/laporan-kecelakaan/ (2017, May 30) 